\title{
Front Matter: Volume 10915
}

, "Front Matter: Volume 10915," Proc. SPIE 10915, Organic Photonic

Materials and Devices XXI, 1091501 (10 May 2019); doi: 10.1117/12.2531136

SPIE. Event: SPIE OPTO, 2019, San Francisco, California, United States 


\section{Organic Photonic Materials and Devices XXI}

Christopher E. Tabor

François Kajzar

Toshikuni Kaino

Editors

5-7 February 2019

San Francisco, California, United States

Sponsored and Published by

SPIE 
The papers in this volume were part of the technical conference cited on the cover and title page. Papers were selected and subject to review by the editors and conference program committee. Some conference presentations may not be available for publication. Additional papers and presentation recordings may be available online in the SPIE Digital Library at SPIEDigitalLibrary.org.

The papers reflect the work and thoughts of the authors and are published herein as submitted. The publisher is not responsible for the validity of the information or for any outcomes resulting from reliance thereon.

Please use the following format to cite material from these proceedings:

Author(s), "Title of Paper," in Organic Photonic Materials and Devices XXI, edited by Christopher E. Tabor, François Kajzar, Toshikuni Kaino, Proceedings of SPIE Vol. 10915 (SPIE, Bellingham, WA, 2019) Seven-digit Article CID Number.

ISSN: 0277-786X

ISSN: 1996-756X (electronic)

ISBN: 9781510624726

ISBN: 9781510624733 (electronic)

Published by

SPIE

P.O. Box 10, Bellingham, Washington 98227-0010 USA

Telephone +1 3606763290 (Pacific Time) · Fax +1 3606471445

SPIE.org

Copyright (C) 2019, Society of Photo-Optical Instrumentation Engineers.

Copying of material in this book for internal or personal use, or for the internal or personal use of specific clients, beyond the fair use provisions granted by the U.S. Copyright Law is authorized by SPIE subject to payment of copying fees. The Transactional Reporting Service base fee for this volume is $\$ 18.00$ per article (or portion thereof), which should be paid directly to the Copyright Clearance Center (CCC), 222 Rosewood Drive, Danvers, MA 01923. Payment may also be made electronically through CCC Online at copyright.com. Other copying for republication, resale, advertising or promotion, or any form of systematic or multiple reproduction of any material in this book is prohibited except with permission in writing from the publisher. The CCC fee code is 0277$786 \mathrm{X} / 19 / \$ 18.00$.

Printed in the United States of America by Curran Associates, Inc., under license from SPIE.

Publication of record for individual papers is online in the SPIE Digital Library.

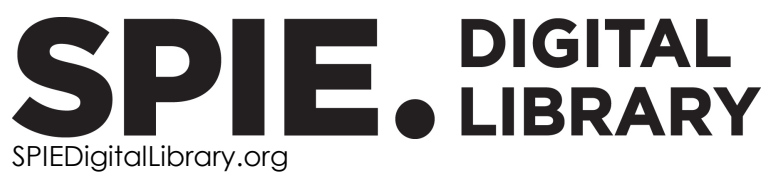

Paper Numbering: Proceedings of SPIE follow an e-First publication model. A unique citation identifier (CID) number is assigned to each article at the time of publication. Utilization of CIDs allows articles to be fully citable as soon as they are published online, and connects the same identifier to all online and print versions of the publication. SPIE uses a seven-digit CID article numbering system structured as follows:

- The first five digits correspond to the SPIE volume number.

- The last two digits indicate publication order within the volume using a Base 36 numbering system employing both numerals and letters. These two-number sets start with $00,01,02,03,04$, 05, 06, 07, 08, 09, 0A, OB ... 0Z, followed by 10-1Z, 20-2Z, etc. The CID Number appears on each page of the manuscript. 


\title{
Contents
}

\author{
$\checkmark \quad$ Authors \\ vii Conference Committee
}

3D PRINTING

$1091502 \quad$ Fabrication of functional nanophotonic devices by multiphoton lithography (Invited Paper) [10915-1]

1091503 3D photo-responsive optical devices manufactured by advanced printing technologies (Invited Paper) [10915-2]

$1091505 \quad$ Additive manufacturing of photoluminescent optics [10915-4]

\section{OLEDs}

$1091508 \quad$ Iridium complexes containing nitro-derivatized isoquinoline ligands for photonic applications [10915-7]

ORGANIC SENSORS

109150 Comparison of different polymers and printing technologies for realizing flexible optical waveguide Bragg grating strain sensor foils [10915-17]

NONLINEAR OPTICS

10915 ON Understanding photophysics of a high concentration platinum (II) chromophore in epoxy (Invited Paper) [10915-22]

PHOTONIC MATERIALS

10915 OR Practical high refractive index resin usable for near-IR and visible wavelengths (Invited Paper) [10915-26] 
10915 OY Space-charge-limited transport in spatially disordered organic materials: a fractionaldimensional approach [10915-33]

\section{NANOPHOTONICS I}

$1091511 \quad$ Wavelength-selective negative photoresist for photolithography suitable for generating microstructures with up to three distinct height levels [10915-36]

$1091512 \quad$ Plasmonic enhancement of absorption in bulk-heterojunction organic solar cells [10915-37]

\section{NANOPHOTONICS II}

1091513 Growth of organic nonlinear nanowires through a one-drop self-assembly method (Invited Paper) [10915-38]

$1091514 \quad$ Enhanced light out-coupling in organic light-emitting diodes (OLED) by patterning the cathode in graded photonic super-crystals [10915-39]

\section{POSTER SESSION}

1091517 Light-inducing birefringence of organic photoanisotropic materials integrated via covalent bonds [10915-42]

1091518 PDMS-based microstructured biosensor [10915-44]

$109151 \mathrm{E} \quad$ Polymerizable ionic liquids for microstructures fabrication [10915-51] 


\section{Authors}

Numbers in the index correspond to the last two digits of the seven-digit citation identifier (CID) article numbering system used in Proceedings of SPIE. The first five digits reflect the volume number. Base 36 numbering is employed for the last two digits and indicates the order of articles within the volume. Numbers start with 00, 01, 02, 03, 04, 05, 06, 07, 08, 09, OA, OB...0Z, followed by 10-1Z, 20-2Z, etc.

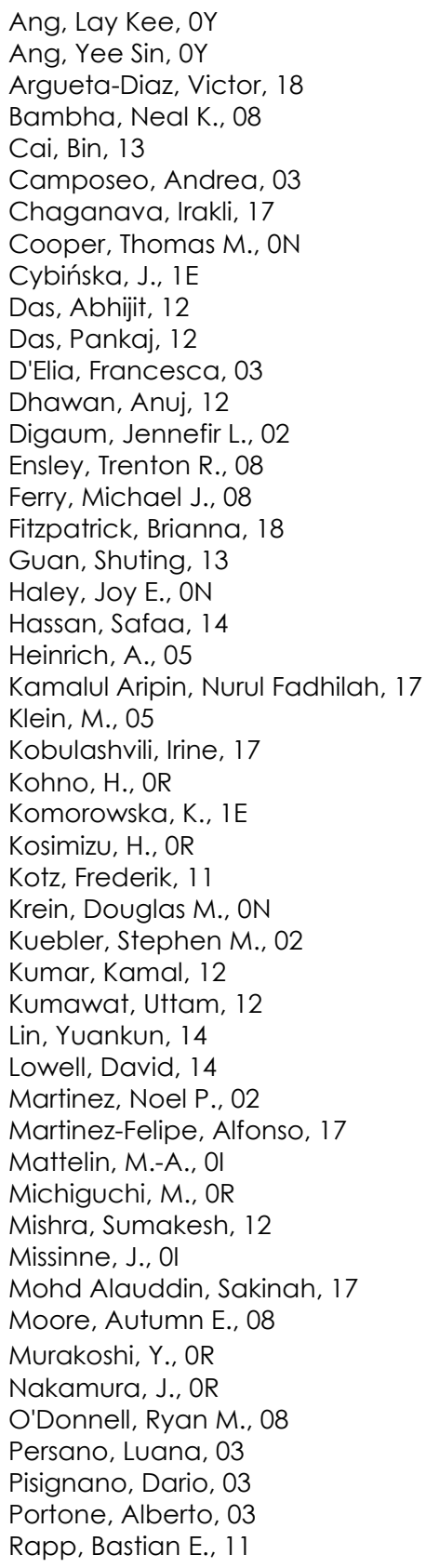

\author{
Renkel, Rachel N., ON \\ Rola, K., 1E \\ Rumpf, Raymond C., 02 \\ Schmid, Max C., 11 \\ Sharma, Rashi, 02 \\ Shensky, William M., III, 08 \\ Shi, Jianmin, 08 \\ Slagle, Jonathan E., ON \\ Smiglak, M., $1 \mathrm{E}$ \\ Steenhusen, S., 05 \\ Stewart, David J., ON \\ Sugihara, Okihiro, 13 \\ Suresh Nair, S., 05 \\ Szukalski, Adam, 03 \\ Teigell Beneitez, N., 0 l \\ Tian, Tian, 13 \\ Tomaru, S., OR \\ Uttiya, Sureeporn, 03 \\ Valle, Cesar L., 02 \\ Van Steenberge, G., 01 \\ Wu, Chenyin, 13 \\ Wussler, Denise, 11 \\ Xia, Chun, 02 \\ Yamauchi, A., OR \\ Yamauchi, K., OR \\ Zajac, A., 1E \\ Zhu, Lanfang, 13 \\ Zubair, Muhammad, OY
}


Proc. of SPIE Vol. 10915 1091501-6

Downloaded From: https://www.spiedigitallibrary.org/conference-proceedings-of-spie on 26 Apr 2023 Terms of Use: https://www.spiedigitallibrary.org/terms-of-use 


\section{Conference Committee}

Symposium Chairs

Connie J. Chang-Hasnain, University of California, Berkeley (United States)

Graham T. Reed, Optoelectronics Research Center (United Kingdom)

Symposium Co-chairs

Sailing He, KTH Royal Institute of Technology (Sweden) and Zhejiang University (China)

Yasuhiro Koike, Keio University (Japan)

Program Track Chairs

James G. Grote, Photonics Consultant (United States)

Shibin Jiang, AdValue Photonics, Inc. (United States)

Conference Chairs

Christopher E. Tabor, Air Force Research Laboratory (United States)

François Kajzar, University Politehnica of Bucharest (Romania)

Toshikuni Kaino, Tohoku University (Japan)

Conference Co-chair

Okihiro Sugihara, Utsunomiya University (Japan)

Conference Program Committee

Chantal Andraud, Ecole Normale Supérieure de Lyon (France)

Werner J. Blau, Trinity College Dublin (Ireland)

Ken Caster, Air Force Office of Scientific Research (United States)

Fabrice Charra, Commissariat à l'Énergie Atomique (France)

Beata J. Derkowska-Zielinska, Nicolaus Copernicus University (Poland)

Raluca Dinu, GigPeak, Inc. (United States)

Manfred Eich, Technische Universität Hamburg-Harburg (Germany)

Alain F. Fort, Institut de Physique et Chimie des Matériaux de Strasbourg (France)

James G. Grote, Air Force Research Laboratory (United States)

Alex K. Y. Jen, University of Washington (United States)

Michael H. C. Jin, Johns Hopkins University Applied Physics Laboratory, LLC (United States) 
Eunkyoung Kim, Yonsei University (Korea, Republic of) Jang-Joo Kim, Seoul National University (Korea, Republic of) Junya Kobayashi, NTT Advanced Technology Corporation (Japan) Yasuhiro Koike, Keio University (Japan) Isabelle Ledoux-Rak, École Normale Supérieure Paris-Saclay (France) Kwang-Sup Lee, Hannam University (Korea, Republic of)

Misoon Y. Mah, Asian Office of Aerospace Research and Development (Japan)

Seth R. Marder, Georgia Institute of Technology (United States)

Antoni C. Mitus, Wroclaw University of Science and Technology (Poland)

Jaroslaw Mysliwiec, Wroclaw University of Science and Technology (Poland)

Robert A. Norwood, College of Optical Sciences, The University of Arizona (United States)

Jean-Michel Nunzi, Queen's University (Canada)

Shuji Okada, Yamagata University (Japan)

Akira Otomo, National Institute of Information and Communications Technology (Japan)

Ileana Rau, University Politehnica of Bucharest (Romania)

Niyazi Serdar Sariciftci, Johannes Kepler University of Linz (Austria)

Devanand K. Shenoy, U.S. Department of Energy (United States)

William M. Shensky III, U.S. Army Research Laboratory (United States)

Kenneth D. Singer, Case Western Reserve University (United States)

Rebecca E. Taylor, Lockheed Martin Space Systems Company (United States)

Jeong-Weon Wu, Ewha Womans University (Korea, Republic of)

Shiyoshi Yokoyama, Kyushu University (Japan)

Roberto Zamboni, Istituto per la Sintesi Organica e la Fotoreattività (Italy)

Wei Zhou, Virginia Polytechnic Institute and State University (United States)

\section{Session Chairs}

1 3D Printing

André-Jean Attias, Institut Parisien de Chimie Moléculaire (France)

2 OLEDS

Stephen M. Kuebler, University of Central Florida (United States)

3 Biophotonics

Christopher E. Tabor, Air Force Research Laboratory (United States)

4 Organic Sensors

Chantal Andraud, Ecole Normale Supérieure de Lyon (France) 
5 EO Polymers

James G. Grote, Photonics Consultant (United States)

$6 \quad$ Nonlinear Optics

Akira Otomo, National Institute of Information and Communications Technology (Japan)

7 Photonic Materials

Okihiro Sugihara, Utsunomiya University (Japan)

8 Organic Semiconductors

William M. Shensky III, U.S. Army Research Laboratory (United States)

9 Nanophotonics I

Eunkyoung Kim, Yonsei University (Korea, Republic of)

10 Nanophotonics II

Ileana Rau, University Politehnica of Bucharest (Romania) 
Proc. of SPIE Vol. 10915 1091501-10

Downloaded From: https://www.spiedigitallibrary.org/conference-proceedings-of-spie on 26 Apr 2023 Terms of Use: https://www.spiedigitallibrary.org/terms-of-use 